\title{
LANDSCAPE-LEVEL INTERACTIONS AMONG UNGULATES, VEgETATION, AND LARGE-SCALE FiRES in Northern Yellowstone National Park
}

\author{
MONICA G. TURNER ^ YEGANG WU $\bullet$ SCOTT M. PEARSON \\ ENVIRONMENTAL SCIENCES DIVISION • OAK RIDGE NATIONAL LABORATORY \\ OAK RIDGE
}

\author{
WILLIAM H. ROMME \\ DEPARTMENT OF BIOLOGY \\ FORT LEWIS COLLEGE \\ DURANGO
}

\author{
LINDA L. WALLACE \\ DEPARTMENT OF BOTANY/ MICROBIOLOGY \\ UNIVERSITY OF OKLAHOMA \\ NORMAN
}

\section{$\downarrow \quad$ INTRODUCTION}

The scale of the 1988 fires in Yellowstone National Park (YNP) raised numerous questions for the management of natural areas subject to large, infrequent disturbances. An important management issue in YNP involves the interaction of large-scale fire with the large assemblage of native ungulates and vegetation dynamics in the landscape. We used landscape modeling and field studies to address basic questions about the effects of fire scale and heterogeneity on resource utilization and survival of free-ranging elk (Cervus elaphus) and bison (Bison bison), and the production and regeneration of preferred forage grasses and aspen in northern Yellowstone Park. More specifically, we asked (1) how fire size interacts with winter severity to control ungulate feeding behavior and survival, both in the initial postfire winter, when fire reduces forage, and in later postfire winters, when fire augments forage; (2) how fire pattern (e.g., clumped vs. dispersed burn sites) modifies the effects of fire size; (3) which environmental factors, including fire, influence selection of feeding areas by wintering ungulates at a variety of scales, from a single feeding station to the entire northern winter range; and (4) how the size and spatial pattern of burning influence regeneration of aspen (Populus tremuloides), a preferred and heavily browsed species in YNP.

We focus on elk and bison because these are by far the most numerous ungulates in the area (Houston 1982), and we have chosen to examine winter grazing and browsing for several reasons. Winter range conditions are the primary determinant of ungulate survival and reproduction in Yellowstone, and winter utilization of the vegetation by ungulates appears to be intense in some areas. Ungulates make distinct foraging choices in the winter as in the rest of the year, and burn patterns may influence those choices in ways that we represent as hypotheses described later. In addition, the activities of animals can be readily monitored in the winter, and the exact locations of feeding and bedding sites can be determined. Travel routes are easily monitored, and the ability to sight animals is high; therefore, group locations and sizes can be readily determined.

This research complements ongoing studies in Yellowstone by expanding the spatial scale at which plant-herbivore dynamics are considered and by explicitly addressing the effects of spatial heterogeneity. We produced a spatially explicit simulation model of the winter range that predicts 
plant and ungulate dynamics under varying fire sizes, fire patterns, winter weather scenarios. The model and field studies will generate quantitative comparisons of the effects of large and small fires on ungulate survival and will thereby permit the simulation of the effects of alternative fire management scenarios.

\section{$\downarrow \quad$ STUDY AREA}

Yellowstone National (YNP) was established in 1872 and encompasses $9000 \mathrm{~km}^{2}$ in the northwest corner of Wyoming and adjacent parts of Montana and Idaho. Elevations in the Park range from 1,500 to more than $3,000 \mathrm{~m}$, and much of the area is covered by Quaternary volcanic deposits that underwent at least three extensive glaciations (Houston 1982). General descriptions can be found for park geology (Keefer 1972); and for physiography, soils and vegetation (Meagher 1973; Barmore 1980; Houston 1982; Despain 1991). The climate of YNP is characterized by long, cold winters and short, cool summers (Diaz 1979; Dirks and Martner 1982). Our study focused on the northern $20 \%$ of the park which is primarily a lower-elevation grassland or sagebrush steppe. The northern Yellowstone elk and bison migrate seasonally between a high-elevation summer range and this lower-elevation winter range (Craighead et al. 1972; Barmore 1980; Houston 1982).

The northern range extends about $80 \mathrm{~km}$ down the Lamar, Yellowstone, and Gardner River drainages (Houston 1982). Approximately $83 \%$ of the winter range for elk is included within YNP (Houston 1982), comprising nearly $80,000 \mathrm{ha}$, and has a warmer, drier climate than the rest of the Park (Diaz 1979; Dirks and Martner 1982). We focused solely on the winter range within the Park boundaries. Most of the soils derive from glacial till deposited during the Pinedale glaciation (Houston 1982) and tend to be higher in silt, clay and organic matter than soils derived from rhyolite, the parent rock of most of YNP (Despain 1991). The drier grasslands are dominated by big sagebrush (Artemisia tridentata), bluebunch wheatgrass (Agropyron spicatum) and Idaho fescue (Festuca idaohensis). Wet sites are dominated by bearded wheatgrass (Agropyron caninum), sedges (Carex spp.) and introduced graminoids such as Kentucky bluegrass (Poa pratensis). More continuous forest occurs at high elevations and on north slopes (see detailed descriptions in Houston 1982 and Despain 1991). At lower elevations, the sagebrush-grasslands are interspersed with coniferous forest, primarily Douglas fir (Pseudotsuga menziesii), and lodgepole pine (Pinus contorta var. latifolia Engelm.); aspen groves (Populus tremuloides); and riparian willow communities.

Natural fires have influenced plant succession on the winter range for a long time (Houston 1973). Tree-ring evidence suggests that eight to ten extensive fires occurred in the area during the last 300-400 years, but no large fires have occurred previously in this century (Houston 1973). Approximately $34 \%$ of the winter range burned during the 1988 fires, including 22\% of the grasslands (Despain et al. 1989). The vegetation has been dynamic during the past century (Houston 1982). Forest cover has increased, mostly on north slopes, and forests have recolonized burned areas, although aspen appears to have declined from 4-6\% to $2-3 \%$ of the winter range. Sagebrush increased in extent on many slopes and exposures. Willows and associated riparian vegetation have shown a net decrease. The production of herbaceous vegetation on the northern range shows substantial annual fluctuations resulting from varied growing conditions, primarily precipitation (Houston 1982; Merrill et al. 1988).

\section{$-\quad$ DISCUSSION}

The spatial scale at which ungulates make foraging choices in the winter is not well known. In our study of micro-scale heterogeneity in forage production and foraging behavior, we established sampling areas across the northern range to compare the spatial pattern of biomass distribution within a forage patch with the spatial pattern of feeding station (i.e., individual feeding "crater" in the snow) locations within a forage patch. During the winter of 1988-89, feeding stations were mapped on an $x / y$ grid in eight $30 \mathrm{~m} \times 30 \mathrm{~m}$ sites and their locations compared with the Poisson distribution. In four of the eight sites, feeding station distributions were no different from Poisson. In the four sites where they were different, stations were slightly aggregated (Morisita's Index) in three sites and uniform in the remaining site. These four sites were characterized by having large areas devoid of vegetation.

To determine whether the feeding station 
distributions represented an underlying pattern in biomass distributions, six $30 \mathrm{~m}$ × $30 \mathrm{~m}$ sampling grids were established across the northern range in 1990. Biomass was sampled every two meters within these grids, and no autocorrelation was found when the distribution was analyzed using geostatistics. We simulated the amount of forage that would be obtained from the grids by alternative ungulate grazing patterns including randomly selected points, an actual pattern of feeding station locations as previously mapped, and a "smart" pattern in which the 30 highest biomass points were sampled. Ungulates that were grazing using either the random or actual pattern would not procure significantly different amounts of biomass at any sites. Only the "smart" pattern yielded significantly more biomass. This indicates that ungulate grazing choices in the winter is at the site scale ( $\geq 30 \mathrm{~m}$ ) and not at the scale of the individual feeding station. This does not meet current theoretical expectations of hierarchical grazing choices.

Our study of landscape-level habitat use focused on ungulate grazing intensity at a broader scale and explored the effect of fire and habitat heterogeneity on winter foraging. Grazing was monitored at 15 study sites for 14 weeks during the winter of 1990-91. The location and intensity of grazing activity within each site was recorded on topographic maps and digitized into a geographic information system. Maps of grazing intensity were compared to map layers of grassland habitat type, elevation, slope, aspect, annual precipitation, and the spatial pattern of fires that occurred in 1988. Analyses were conducted at scales of an individual map cell (1 ha) and an individual study area (1311144 ha). Elevation, precipitation, and grassland type were found to be highly correlated. Steep slopes also were positively correlated with southerly aspects.

The spatial extent of grazing activity increased in mid-winter then declined in late winter. Except for a preference for burned areas, ungulates were not selective in early winter, using habitats as defined by grassland type and topography according to their availability. During mid-to late winter, ungulates were more selective; grazing activity was greatest in areas that were burned and located at lower elevations with steep, south-facing slopes. At the scale of a study site, the spatial pattern of burning (clumped vs. dispersed) was not correlated with grazing intensity.
Our detailed study of aspen stand dynamics revealed that most of the extant tree-sized aspen on the winter range became established in the late 1800's. Aspen clones are persisting through root sprouting, but few tree-sized stems have regenerated during the 20th century, in part because of heavy winter browsing of sprouts by elk. It has been hypothesized that the extensive fires in the past periodically stimulated abundant browse and forage production across a large portion of the landscape, thereby permitting some aspen sprouts to escape browsing long enough to regenerate tree-sized stands. We tested this hypothesis following the 1988 fires by sampling sprout density and browsing intensity in six burned aspen stands, in six unburned stands located close to the fires, and in six "remote" unburned stands located 2 to $4 \mathrm{~km}$ from the fires. Sprout densities in the spring and fall of 1990 and 1991 were significantly greater in the burned stands than in the unburned stands. Protein analysis of aspen sprouts sampled in the autumn of 1990 indicate that sprouts from burned stands contain slightly more protein ( $7 \%$ ) than sprouts from unburned stands ( 6\%). However, there were no significant differences in browsing intensity; all stands were heavily browsed in both winters and lightly browsed in the summers. We conclude that the fires of 1988 probably will not lead to substantial regeneration of tree-sized aspen stands on the northern range. Aspen tree regeneration apparently was episodic even before the Park was established in 1872. The episode of tree regeneration in the late 1800 's apparently resulted not just from extensive fires, but from a combination of factors, including altered elk foraging behavior in the presence of wolves, lower elk numbers, and cooler, wetter climatic conditions. This combination of conditions has not occurred again since 1990.

The field studies addressed the influence of the 1988 fire patterns and generally were limited to the 1990-91 winter. It is possible that the effect of fire on ungulates depends on set of interacting factors, including fire size, fire pattern, and winter conditions. A factorial experiment in which these factors are varied systematically across a landscape is logistically impossible. The 1988 fires offer valuable insight into ungulate responses to broad-scale disturbances, but even such natural experiments do not encompass a wide range of conditions. Consequently, models linking the responses of ungulates to environmental heterogeneity are needed. 
Our first step in model development was to explore alternative simulation algorithms by using a relatively small landscape and known conditions. Ungulate winter grazing was simulated on simple random and actual landscape patterns using an individual-based modeling approach to explore the effect of landscape heterogeneity on foraging dynamics. The landscape was represented as a 100 x 100 grid with each cell considered to either be a resource or nonresource site. Random maps were generated by specifying the proportion, $p$, of the landscape occupied by resource sites. Actual landscape maps were obtained from the spatial arrangement of sagebrush-grassland habitats in subsections of northern Yellowstone National Park, Wyoming. Each resource site was assigned an initial forage abundance, and a specified number of ungulates were distributed randomly across the landscape on resource sites. Three alternative searchand-movement rules, which incorporated different movement scales and assumptions about ungulates' knowledge of the landscape, were compared. Grazing was simulated as a recipient-determined donor-controlled flow with a nonlinear feedback. Daily energy balances were computed for each ungulate by subtracting energy cost from energy gain, and ungulates were assumed to die when they reached $70 \%$ of their lean body weight.

Simulation results with this initial model suggested that when resources were abundant across the landscape (i.e. high p), the search-and-movement rule selected to simulate foraging was not important. That is, a variety of strategies should suffice under high-resource conditions, and there was no benefit to having a more efficient rule. However, when resources were scarce (e.g. low p or high ungulate densities), then the ability to discern resource abundances and to move over greater distances resulted in lower mortality. For a given $p$, the difference between a fragmented (i.e., random) and aggregated (i.e., real) arrangement of resource sites was only pronounced when the ability of the animals to move was very limited. In these situations, survival was always greater in the real landscapes. Individual-based spatial models developed for specific landscapes and species could be quite valuable in enhancing our understanding of landscape dynamics and large herbivores.

The full Northern Yellowstone Park (NOYELP) model is a spatially explicit individualbased simulation model developed to explore the effects of fire scale and pattern on the winter foraging dynamics and survival of free-ranging elk (Cervus elaphus) and bison (Bison bison) in northern Yellowstone National Park. The NOYELP model simulates the search, movement, and foraging activities of individuals or small groups of elk and bison. The 77,020 ha landscape is represented as a gridded irregular polygon with a spatial resolution of 1 ha. Forage intake is a function of an animal's initial body weight, the absolute amount of forage available on a site, and the depth and density of snow. When the energy expenditures of an animal exceed the energy gained during a day, the animal's endogenous reserves are reduced to offset the deficits. Simulations are conducted with a 1-day time step for a duration of 180 days, approximately November 1 through the end of April. Simulated elk survival for three winters $(1987-88$; 1988-89; 1990 91) agreed with observed data.

A factorial simulation experiment was conducted to explore the effects on ungulate survival of fire size, fire pattern, and winter severity during an initial postfire winter (when no forage is available in burned areas) and a later postfire winter (when forage is enhanced in burned areas). Initial ungulate population sizes were held constant at 18,000 elk and 600 bison. Winter severity played a dominant role in ungulate survival. When winter conditions were extremely mild, even fires that affected $60 \%$ of the landscape had no effect on ungulate survival during the initial postfire winter. The effects of fire on ungulate survival become important when winter conditions were normal to severe, and effects were apparent in both the initial and later postfire winters. The spatial patterning of fire influenced ungulate survival if fires covered small to moderate proportions of the landscape (e.g., $15 \%$ or $30 \%$ ) and if winter snow conditions were moderate to severe. Ungulate survival was higher with a clumped than with a fragmented fire pattern, suggesting that a single, large fire is not equivalent to a group of smaller disconnected fires. The interaction between fire scale and spatial pattern suggests that knowledge of fire size alone is not always sufficient to predict ungulate survival.

The simulation model is written in standard FORTRAN, contains 14 subroutines and the main program, and runs in a workstation environment (e.g., Sun Sparc II and DEC 5000 workstations). The source code includes the ability to generate graphical output in real time during the simulations. 
A procedure written in the $\mathrm{C}$ language provides a bridge for passing the output matrix to PV-WAVE (Precision Visuals' Workstation Visualization Environment), which provides real-time display of landscape changes, ungulate movement, and snow and resource distributions. The visualization includes both maps and graphs, and the user selects the output to display for any given simulation. For example, the following data can be displayed for each of the six ungulate categories: (1) mean forage consumed per ungulate; (2) mean daily energy gain, cost and balance; (3) number of animals surviving; (4) number of ungulates moving daily; and (5) mean daily moving distance. In addition, one can view graphs of landscape characteristics such as the number of resource patches, average patch size, largest patch size, and total available forage for elk and bison.

Several general conclusions regarding the effects of fire on the ungulates and vegetation of northern YNP emerge from our studies. First, it is important to specify the scale at which we pose our questions. For example, ungulates forage randomly at fine scales ( $<1 \mathrm{ha}$ ) wherever forage is available, but habitat selection is apparent at intermediate scales (ca. $1 \mathrm{~km}^{2}$ ) and at the scale of the entire winter range $\left(800 \mathrm{~km}^{2}\right)$. Scale also is important with regard to fire size and the effects of fire pattern. With very large fires ( $>60 \%$ of the winter range), fire pattern has little effect on ungulate survival. With fires of intermediate size, however, ungulate survival is higher with a clumped than with a fragmented fire pattern, suggesting that a single, large fire is not equivalent to a group of smaller disconnected fires. Secondly, there are other important variables in northern YNP that may completely overshadow effects of fire under certain circumstances. The single most powerful factor controlling ungulate foraging and survival is snow depth and density. Additional variables also may overshadow fire effects, e.g., uniformly heavy browsing of aspen sprouts after 1988 that appears to be preventing tree regeneration, regardless of fire-stimulated increases in sprout density. Third, fire interacts strongly with other controlling variables in northern YNP. For example, elk can endure either a severe winter without fire or a large fire followed by a mild winter; however, the combination of a large fire and a severe winter leads to very low survival. Therefore, predictions of ungulate or plant dynamics based on only one factor are unlikely to be accurate.

\section{LITERATURE CITED}

Barmore, W. J. 1980. Population characteristics, distribution and habitat relationships of six ungulates in northern Yellowstone National Park. Final Report. Research Division, Yellowstone National Park, Wyoming.

Craighead, J. J., H. Atwell and B. W. O'Gara. 1972. Elk migrations in and near Yellowstone National Park. Wildlife Monographs 29:6-48.

Despain, D. G. 1991. Yellowstone Vegetation: Consequences of Environment and History. Roberts Rinehart Publishing Co.

Despain, D., A. Rodman, P. Schullery and H. Shovic. 1989. Burned area survey of Yellowstone National Park: the fires of 1988. Unpublished report, Division of Research and Geographic Information Systems Laboratory, Yellowstone National Park, Wyoming.

Diaz, H. F. 1979. Ninety-one years of weather records at Yellowstone National Park, Wyoming, 1887-1977. National Oceanic and Atmospheric Administration, Environmental Data and Information Service, National Climatic Center, Asheville, North Carolina.

Dirks, R. A., and B. E. Martner. 1982. The climate of Yellowstone and Grand Teton National Parks. Occasional Paper No. 6, U.S. National Park Service, Washington, D.C.

Houston, D. B. 1973. Wildfires in northern Yellowstone elk: ecology and management. MacMillan Publishing Co., New York.

Keefer, W. R. 1972. Geologic story of Yellowstone National Park. Geological Survey Bulletin 1347. Washington, D.C. U.S. Govt. Printing Office.

Meagher, M. M. 1973. The bison of Yellowstone National Park. National Park Service Monograph Series, Number One. 
Merrill, E. H., M. S. Boyce, R. W. Marrs and M.

K. Bramble-Brodahl. 1988. Grassland phytomass, climatic variation and ungulate population dynamics in Yellowstone National Park. Final Report. Research Division, Yellowstone National Park, Wyoming. 